\title{
Pollination and Floral Biology of a Rare Morning Glory Species Endemic to Thailand, Argyreia siamensis
}

\author{
Awapa Jirabanjongjit ${ }^{1}$, Paweena Traiperm ${ }^{1}$, Tomoki Sando ${ }^{2}$ and Alyssa B. Stewart $1, *$ (D) \\ 1 Department of Plant Science, Faculty of Science, Mahidol University, Bangkok 10400, Thailand; \\ awapa.jia@student.mahidol.ac.th (A.J.); paweena.tra@mahidol.edu (P.T.) \\ 2 Thai-Asahi Co., Ltd., Nakhon Ratchasima 30190, Thailand; t.sando.thaiasahi@gmail.com \\ * Correspondence: alyssa.ste@mahidol.edu
}

Citation: Jirabanjongjit, A.; Traiperm, P.; Sando, T.; Stewart, A.B. Pollination and Floral Biology of a Rare Morning Glory Species Endemic to Thailand, Argyreia siamensis. Plants 2021, 10, 2402. https://doi.org/10.3390/ plants10112402

Academic Editors: Bartosz Jan Płachno and Javier Rodrigo

Received: 1 October 2021

Accepted: 4 November 2021

Published: 7 November 2021

Publisher's Note: MDPI stays neutral with regard to jurisdictional claims in published maps and institutional affiliations.

Copyright: (c) 2021 by the authors. Licensee MDPI, Basel, Switzerland. This article is an open access article distributed under the terms and conditions of the Creative Commons Attribution (CC BY) license (https:// creativecommons.org/licenses/by/ $4.0 /)$.

\begin{abstract}
Argyreia siamensis is extremely rare, and very little is known about its reproduction. The species has colorful flowers that seem likely to attract pollinators, but population sizes are typically small (<30 individuals). To determine whether poor reproduction contributes to its rarity, we investigated its mating system and potential pollinators in two populations. We also examined the staminal trichomes and floral nectary to investigate their role in pollinator attraction. The mating system was assessed with a bagging experiment and pollinator visits were recorded with action cameras. Additionally, we tested the staminal trichomes and floral nectary for terpenes and flavonoids and examined floral nectary micromorphology via scanning electron microscope and compound light microscope. Our results reveal that $A$. siamensis is self-incompatible and dependent on pollinators; the western population was pollinated by bees (Meliponini and Amegilla), while the eastern population was mainly pollinated by skipper butterflies (Hesperiidae). Both staminal trichomes and the floral nectary appear to contribute to pollinator attraction through the presence of terpenes and flavonoids (in both secretory structures) and nectariferous tissue and nectarostomata (in the nectary). Our results indicate that $A$. siamensis has reliable and effective pollinators and that insufficient pollination is likely not a primary cause of its rarity.
\end{abstract}

Keywords: breeding system; Convolvulaceae; histochemistry; floral nectary; pollinators

\section{Introduction}

Tropical regions are important biodiversity hotspots [1,2], yet they are also the regions where we are still missing the most information [3]. Joppa et al. [3] estimated that $21 \%$ of flowering plants are still undescribed, and these "missing" species are most likely to be tropical species with small geographic ranges. Additionally, tropical species are more likely to be classified as Data Deficient in the IUCN Red List. For example, $17.1 \%$ of species in South and Southeast Asia are listed as Data Deficient (4,890 out of 28,629 species), while only $6.3 \%$ of species in North America are listed as Data Deficient (734 out of 11,787 species) (IUCN Red List, data retrieved 8 August 2021). Moreover, numerous studies have cautioned that Data Deficient taxa are often classified as such because they are not common, which means that many of them may actually be threatened [4-7].

One such species with a small geographic range, few known populations, and only limited information is Argyreia siamensis (Craib) Staples (Convolvulaceae), a rare morning glory species that is endemic to Thailand $[8,9]$. Argyreia siamensis has tubular-funnelform flowers that have a white corolla tube and bright purple corolla lobes. Flowering occurs from July to November, and fertilized flowers develop into brown berries with red sepals [10]. This species was originally known to occur only in the northern and western parts of Thailand, although a population was also recently discovered in an eastern province. While this species was initially described in 1911 [11], we still know very little about its ecology and causes of rarity. The species produces large, colorful flowers that seem 
likely to attract pollinators, but population sizes are small (typically less than 30 individuals) and no nectar is observed within flowers (Awapa Jirabanjongjit, personal observation), raising the question of whether insufficient pollination is one factor contributing to its rarity. The objective of this study was, therefore, to study the plant-pollinator interactions of A. siamensis, examining a population in western Thailand and a population in eastern Thailand. Specifically, we examined the mating system (via a pollination experiment), potential pollinators (by observing floral visitors), and floral attractants and rewards (using anatomical and histochemical techniques). Such information is important for assessing the conservation status of $A$. siamensis, which is currently labeled as data deficient.

\section{Results}

\subsection{Mating System}

In the western population, fruit and seed sets were found only in the open (natural) and hand cross-pollinated treatments. LMM results revealed that treatment significantly influenced fruit weight $\left(X_{3}^{2}=44.7, p<0.001\right.$; Figure 1A). Tukey's post hoc further revealed that the open and hand cross-pollinated treatments produced significantly heavier fruits than the closed and hand self-pollinated treatments $(p<0.001$; Figure 1A). As the close and hand self-pollinated treatments did not produce seeds, only open and hand cross-pollinated treatments could be compared for seed weight, and there was no significant difference between the two treatments $\left(X_{1}^{2}=0.31, p=0.58\right.$; Figure $\left.1 \mathrm{~B}\right)$. When examining ovary diameter in the eastern population, LMM results revealed significant differences between treatments overall $\left(X_{3}^{2}=11.5, p=0.01\right)$, but the post hoc test revealed only marginally significant differences between the open and hand self-pollinated treatments and the open and closed treatments $(p<0.1$; Figure 2$)$.

(A)

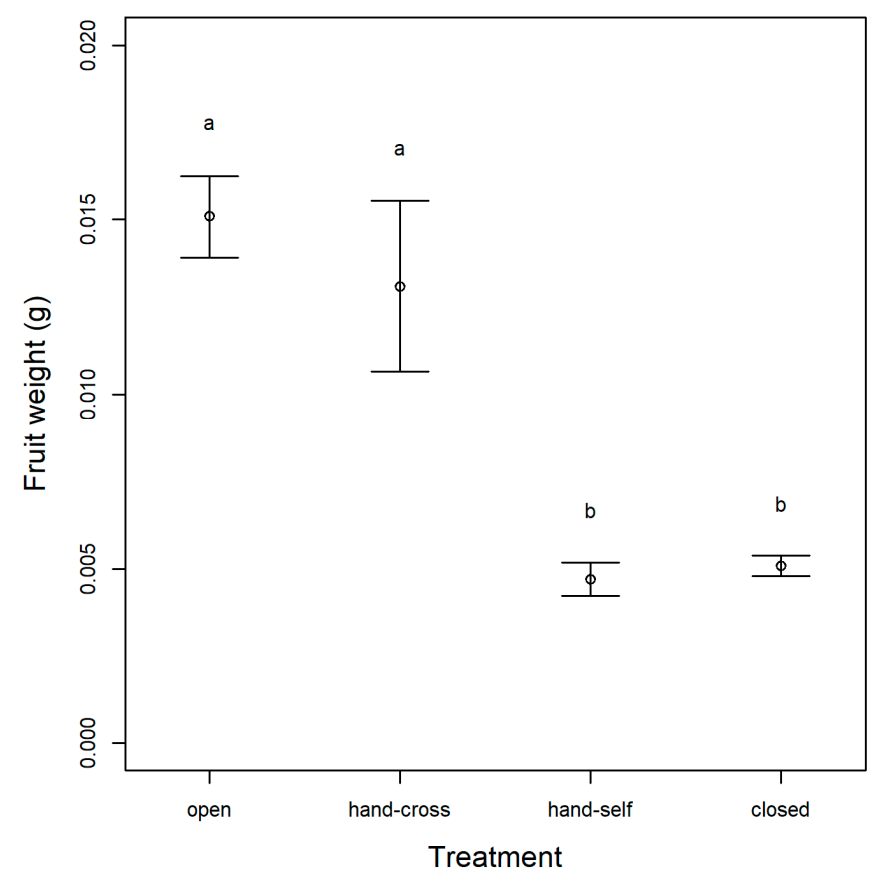

(B)

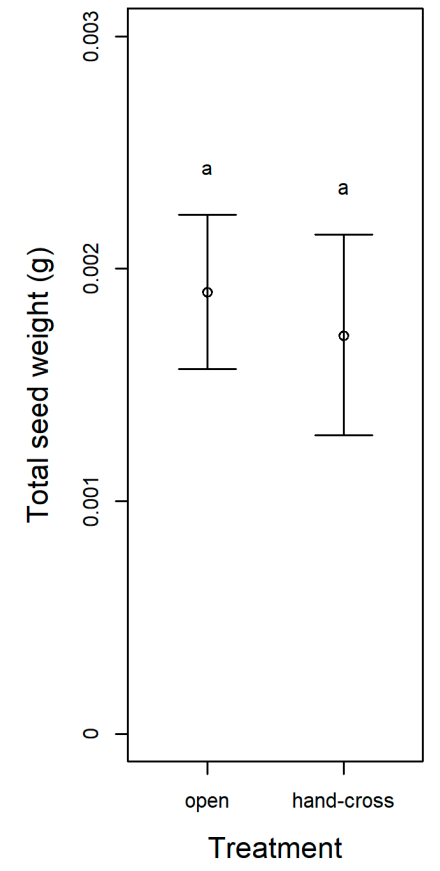

Figure 1. Results of the pollination experiment conducted on Argyreia siamensis in the western population (Ratchaburi, Thailand) showing (A) fruit weight and (B) total seed weight for each experimental treatment (open, hand cross-pollinated, hand self-pollinated, and closed) (mean \pm SE). The hand self-pollinated and closed treatments never produced seeds, so these treatments are absent from the graph on the right. Within each graph, treatments with different letters are significantly different $(p<0.05)$. 


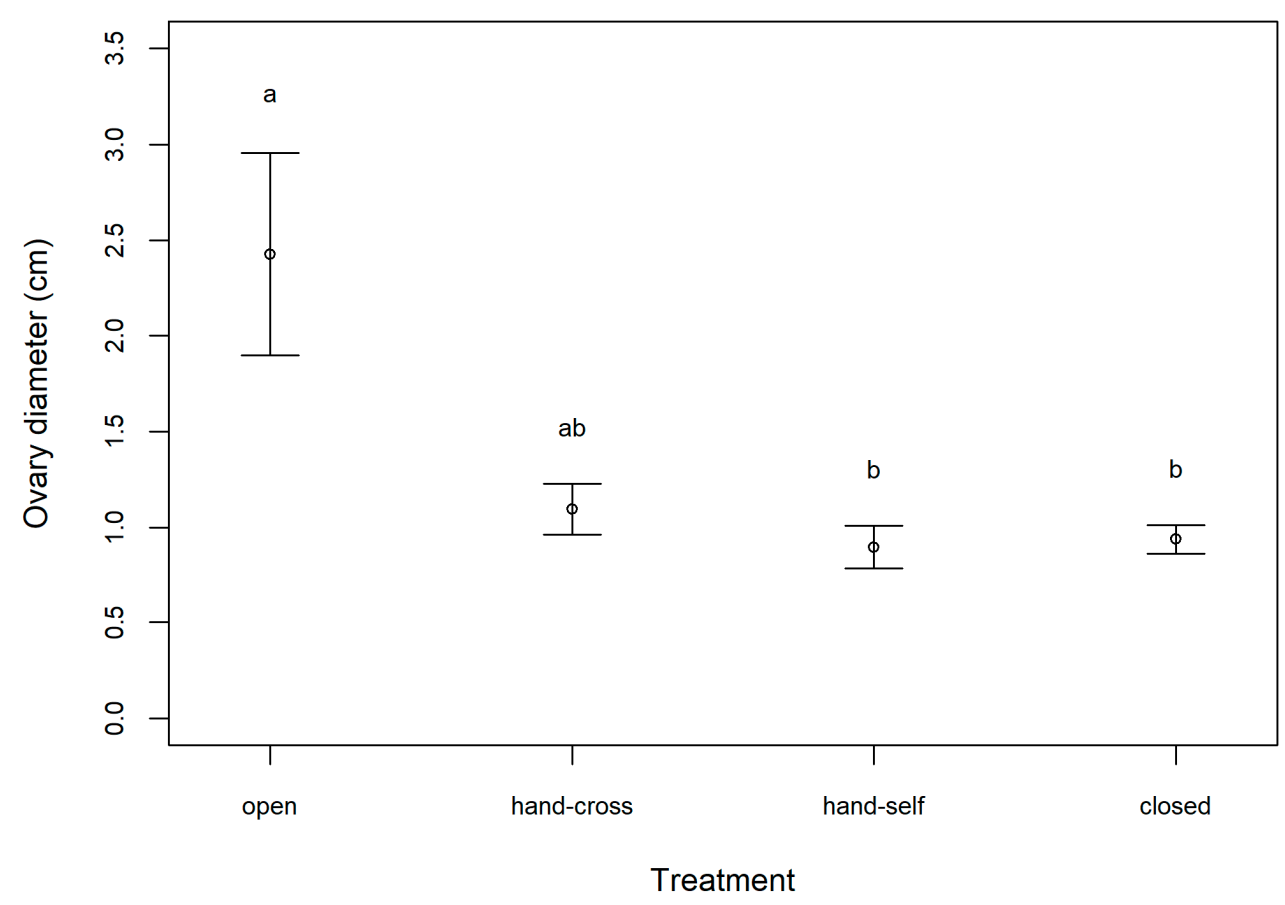

Figure 2. Results of the pollination experiment conducted on Argyreia siamensis in the eastern population (Nakhon Ratchasima, Thailand) showing ovary diameter for each experimental treatment (open, hand cross-pollinated, hand self-pollinated, and closed) (mean $\pm \mathrm{SE}$ ). Treatments with different letters are marginally significantly different $(p<0.10)$.

\subsection{Pollinator Observations}

In the western population, the only observed animal visitors were blue-banded bees (Amegilla sp.; Figure 3A), sweat bees (Lasioglossum sp.), and stingless bees (tribe Meliponini; Figure 3B). Based on their behavior, all three taxa were potential pollinators. Meliponini primarily visited between 06.00 and $08.00 \mathrm{~h}$, and then visits declined. They typically landed on the stigmas or stamens while foraging for pollen, and sometimes crawled inside the flower for nectar. Amegilla bees mostly visited between 07.00 and $14.00 \mathrm{~h}$. Amegilla bees are substantially larger than Meliponini bees (Figure 3), and when they crawled into the corolla tube to forage on nectar, their thorax visibly contacted the stigmas and stamens, and pollen was visible along the dorsal thorax. We also observed a Lasioglossum sweat bee visit once, and it traveled along the stigmas and anthers in the process of searching for nectar. The visitation rates of these three taxa were significantly different $\left(X_{2}^{2}=14.88\right.$, $p<0.001$; Figure 4A). Lasioglossum sweat bees visited flowers significantly less often than Amegilla blue-banded bees $(p=0.016)$, and Meliponini stingless bees $(p=0.004)$, but the visitation rates of Amegilla and Meliponini bees were not significantly different $(p=0.755)$ (Figure 4A).

In the eastern population, we observed seven diurnal and three nocturnal animal taxa visit the flowers. Four taxa (nocturnal slugs and snails, and two diurnal ant taxa) are likely not true pollinators. The slugs and snails foraged on the flowers (including the corolla and some of the floral reproductive parts), while two of the ant taxa never contacted the stigmas or anthers. Among the animals that likely contribute to the pollination of A. siamensis (i.e., contacted stigmas and anthers), we observed two species of skipper butterflies (Pelopidas sp. and Udaspes folus; Figure 3C,D), syrphid flies (Syrphidae), stingless bees (Meliponini), and two ant taxa (one diurnal and one nocturnal). However, four of these potential pollinator taxa (Pelopidas sp., Meliponini, Syrphidae sp., and unknown ant 1) were only observed visiting flowers once, and one taxon (unknown ant 2) was only observed twice. The most frequent pollinator of A. siamensis in the eastern population was $U$. folus, which would land on the corolla and insert their proboscis into the corolla tube to collect nectar, contacting floral 
reproductive parts in the process. Visitation rates of these six taxa were significantly different $\left(X_{5}^{2}=13.31, p=0.02\right)$. Udaspes butterflies visited flowers significantly more often than Pelopidas butterflies $(p=0.048)$, syrphid flies $(p=0.045)$, and unknown ant sp. $1(p=0.048)$ but not Meliponini stingless bees $(p=0.10)$, or unknown ant sp. $2(p=0.25)$ (Figure $4 \mathrm{~B})$.

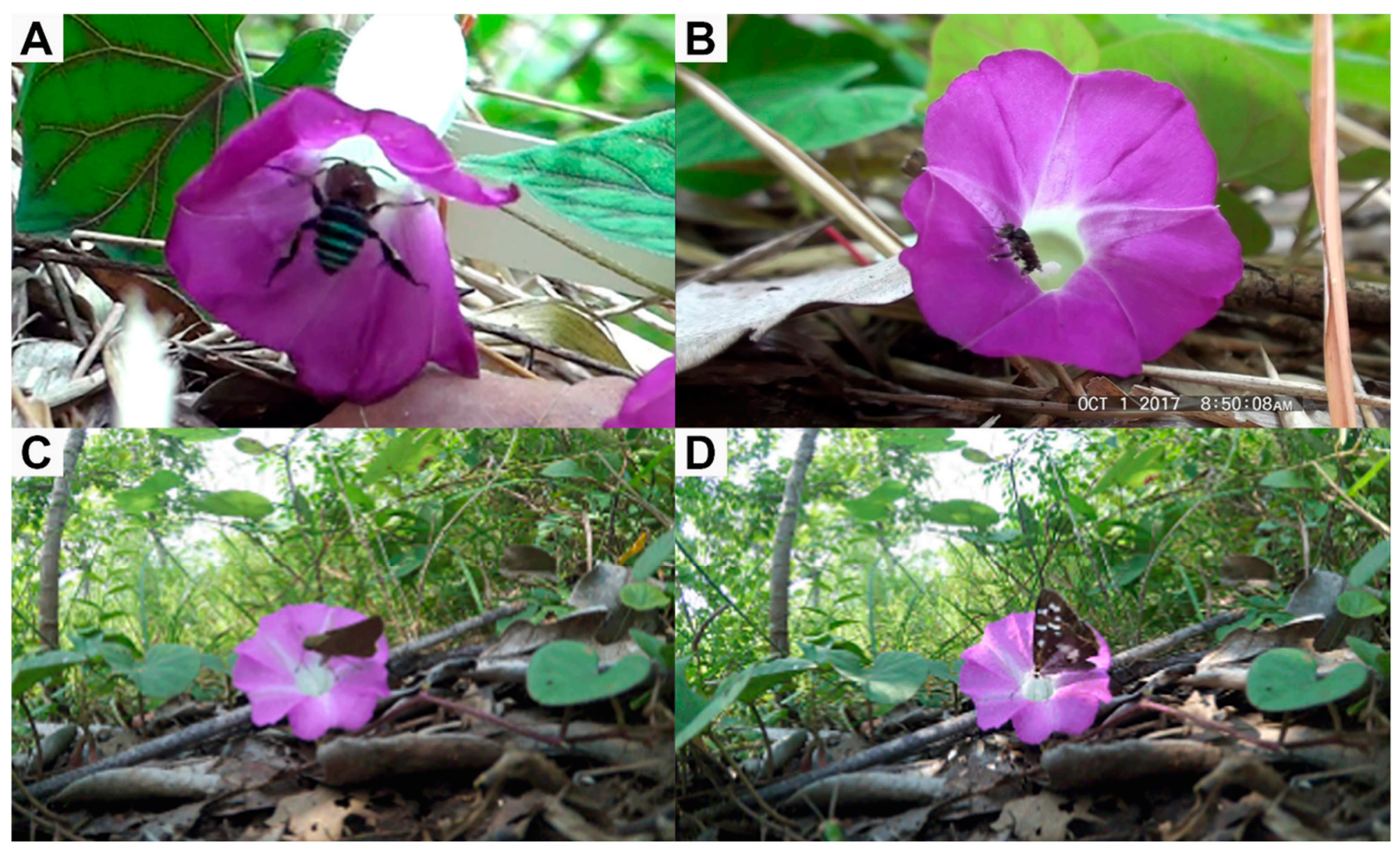

Figure 3. Common pollinators of Argyreia siamensis: (A) Amegilla sp., (B) Meliponini sp., (C) Pelopidas sp., and (D) Udaspes folus.

(A)

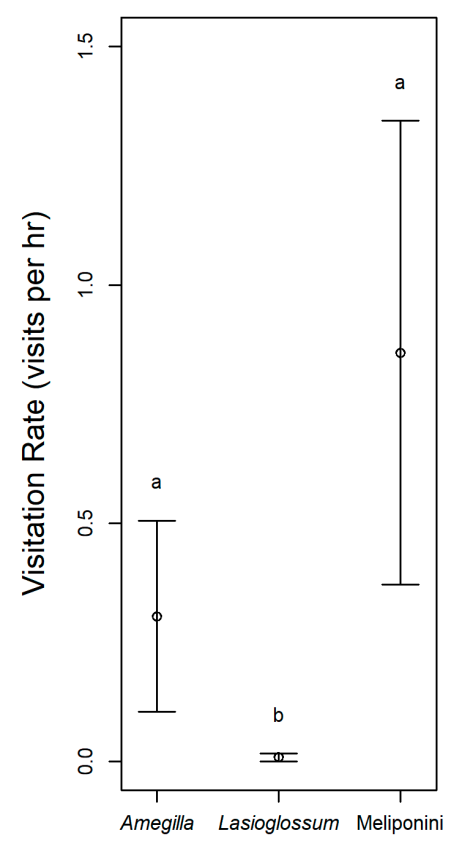

(B)

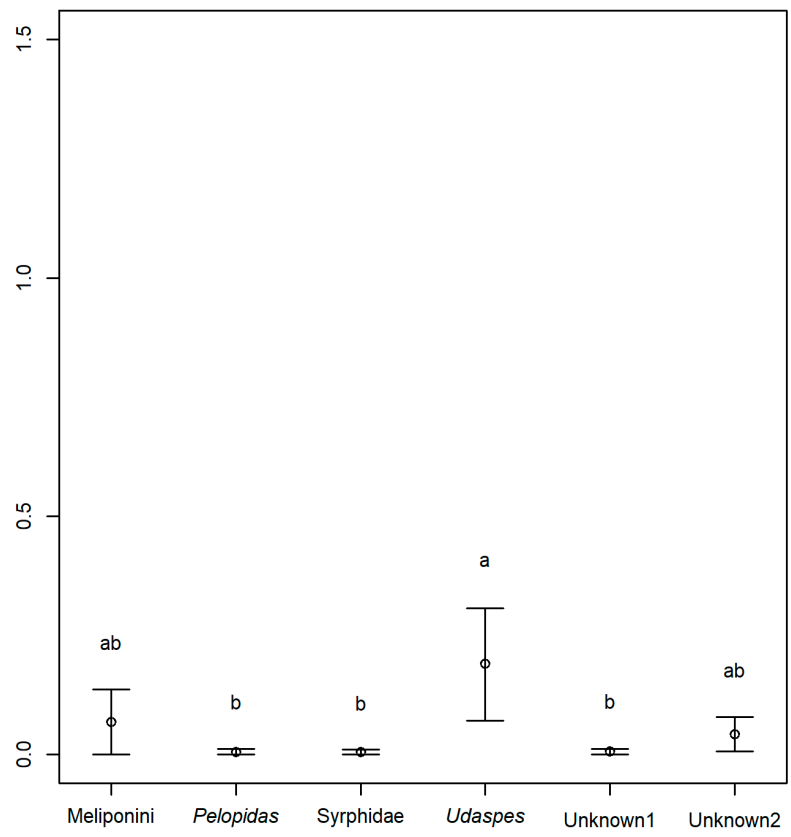

Figure 4. Pollinator visitation rates (mean \pm SE) at Argyreia siamensis flowers in (A) the western study population (Ratchaburi, Thailand) and (B) the eastern study population (Nakhon Ratchasima, Thailand). Within each graph, the visitation rates of pollinator taxa with different letters are significantly different $(p<0.05)$. 


\subsection{Histochemistry}

We detected terpenes and flavonoids in both the floral nectary (Figure 5A,B) and the staminal trichomes (Figure 5C,D). Our investigation of autofluorescence under ultraviolet wavelengths revealed that the floral nectary did not fluoresce, but the staminal trichomes did, especially at the head of the trichomes (Figure 5E,F).

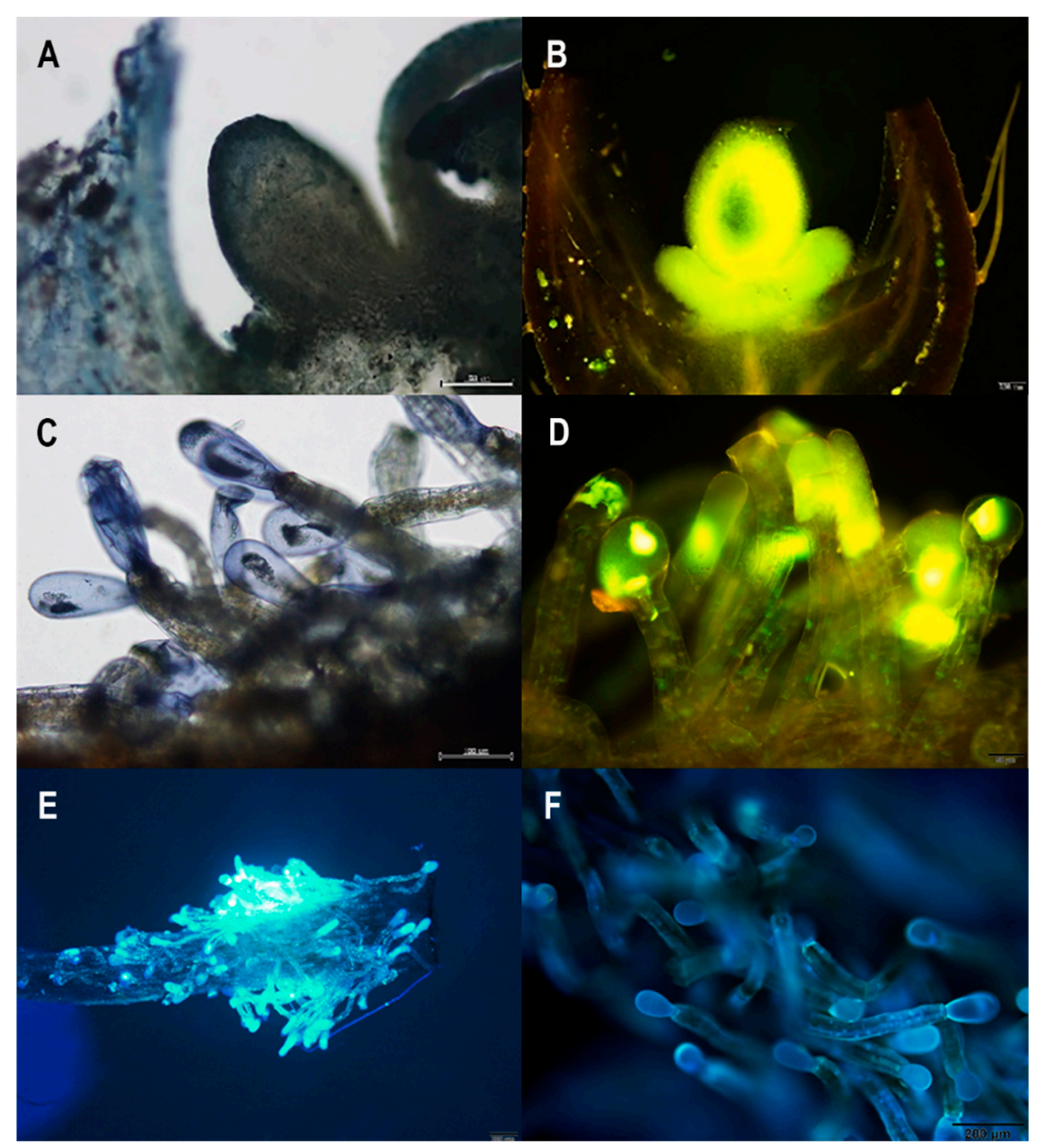

Figure 5. Histochemical results of (A,B) the floral nectary and (C-F) staminal trichomes of Argyreia siamensis. The floral nectary was positive for both (A) terpenes, stained with NADI reagent, and (B) flavonoids, stained with Naturstoff reagent A. Similarly, the staminal trichomes were positive for both (C) terpenes, stained with NADI reagent, and (D) flavonoids, stained with Naturstoff reagent A. Moreover, (E,F) normal, unstained staminal trichomes viewed under a UV filter demonstrated natural fluorescence.

\subsection{Floral Nectary Anatomy and Micromorphology}

The floral nectary of $A$. siamensis is a very pale yellow, has a discoidal shape, and forms a ring surrounding the lower portion of the superior ovary at the base of the receptacle (Figure 6A,C,E). The scanning electron microscope revealed stomata scattered across the apical surface of the floral nectary (Figure 6A,B). Anatomically, the transverse (Figure 6C,D) and longitudinal (Figure $6 \mathrm{E}, \mathrm{F}$ ) sections of the floral nectary revealed the epidermis and ground tissue, which was composed of two regions, the nectariferous parenchyma, and subnectariferous parenchyma. The epidermis was arranged in a single-cell layer that was oriented periclinally ridged, and cuticle and trichomes were absent. Below the epidermis, nectariferous parenchyma cells were larger than the epidermis cells, and they consisted mainly of oval cells that were loosely organized. Within the nectariferous parenchyma were secretory ducts. The subnectariferous parenchyma cells were located below the 
nectariferous parenchyma and were similar in size to the nectariferous parenchyma cells but had less dense cytoplasm. The subnectariferous parenchyma cells were oval-shaped and exhibited packed orientation.

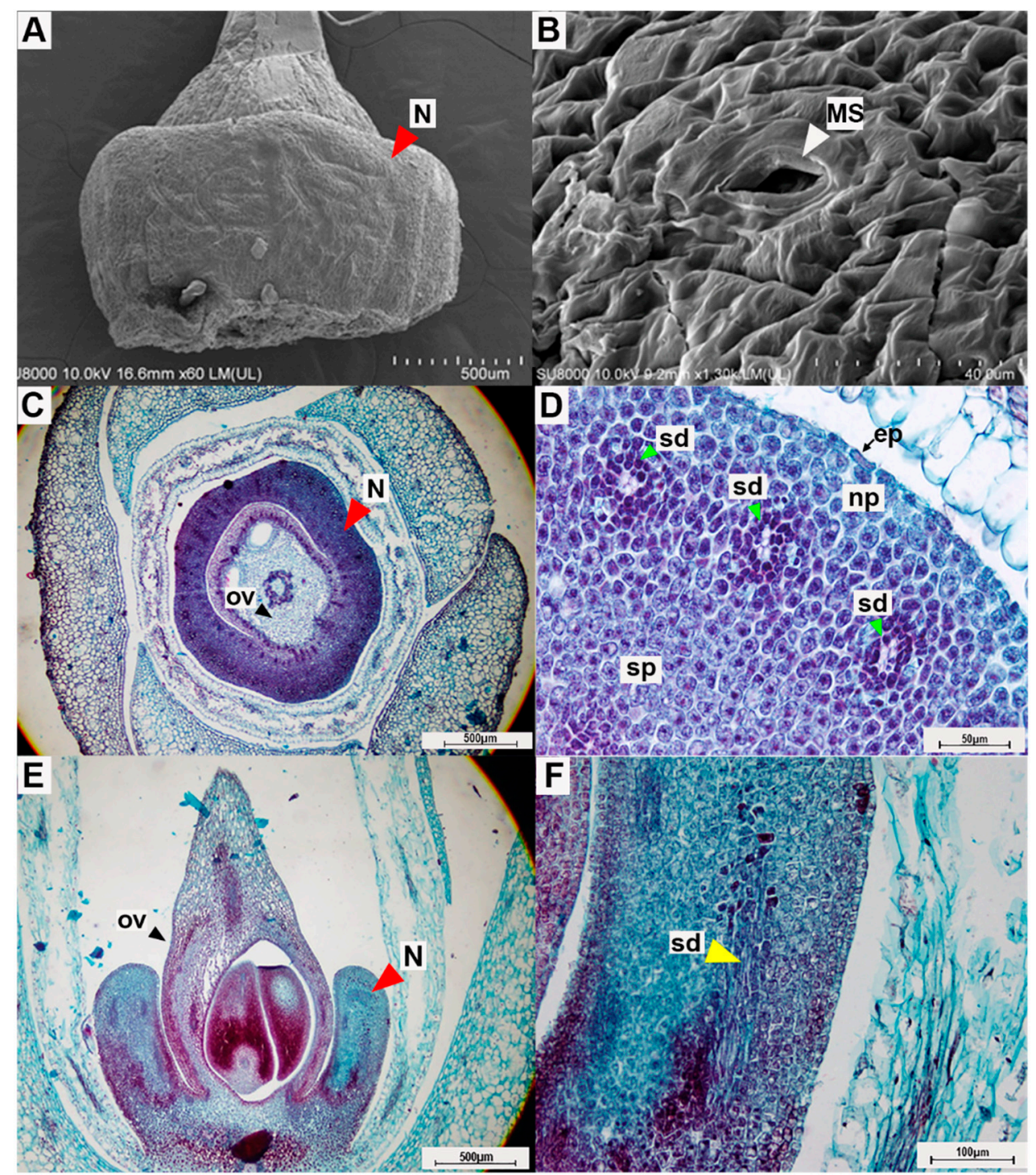

Figure 6. Photographs from micromorphological investigation of the floral nectary of Argyreia siamensis: (A) the entire floral nectary (which surrounds the ovary) and (B) surface of the floral nectary viewed under a scanning electron microscope; (C) transverse section of a mature flower showing the nectary and (D) transverse section showing close-up details of the nectary tissue; (E) longitudinal section of the flower and (F) longitudinal section of the floral nectary showing a close-up view of the secretory duct. In photos C-F, sections were stained with safranin-O and fast green. Abbreviations: $\mathrm{N}=$ nectary, MS = modified-stomata, ep = epidermis, ov = ovary, $\mathrm{np}=$ nectariferous parenchyma, $\mathrm{sp}=$ subnectariferous parenchyma, $\mathrm{sd}=$ secretory duct. Scale bars: (A) $500 \mu \mathrm{m}$; (B) $40 \mu \mathrm{m}$; (C) $500 \mu \mathrm{m}$; (D) $50 \mu \mathrm{m}$; (E) $500 \mu \mathrm{m}$; (F) $100 \mu \mathrm{m}$.

\section{Discussion}

\subsection{Mating System}

The pollination experiments revealed that $A$. siamensis is self-incompatible, as both the closed and hand self-pollination treatments did not set fruit or seed. This finding is consistent with previous studies reporting self-incompatibility in Convolvulaceae species (i.e., Ipomoea wolcottiana [12], I. bahiensis [13], I. trifida [14], I. pes-caprae [15]), although the family appears to have diverse mating systems, as other studies have reported self-compatible 
species (i.e., I. hederacea var. integriuscula [16]; I. nil, Merremia aegyptia, and Jacquemontia evolvuloides [13]; I. carnea subsp. fistulosa [17]), and species with mixed mating systems (i.e., I. habeliana [18], Calystegia [19], M. macrocalyx [20]). Self-incompatibility is an important mechanism that promotes cross-pollination [21,22]. However, self-incompatible species are highly dependent on pollinators, and require reliable and effective pollinators for pollen transfer [23], as insufficient or ineffective visitation can lead to pollen limitation [24-26].

Our pollination experiments further revealed that $A$. siamensis does not suffer from pollen limitation in our study populations, as our measures of pollination success (fruit weight, seed weight, and ovary diameter) did not differ significantly between the open and hand cross-pollination treatments. Pollen limitation is generally more common in self-incompatible species than self-compatible species [19,27], and previous studies have observed pollen limitation in self-incompatible morning glory species [19,28-30]. Various causes for pollen limitation have been reported, including inadequate pollinator visits (Merremia palmeri [28]), small population sizes (Calystegia collina [29]), and poor quality pollen loads (Ipomoea hederacea and I. indica [30]). Moreover, pollen limitation may occur when self-incompatible plants experience fertilization limitation [31,32], as was reported for C. hederacea and C. japonica, which experienced fertilization limitation due to an insufficient number of compatible pollen grains [19]. In contrast to the above studies, pollen limitation was not observed in the self-incompatible Ipomoea asarifolia [33], similar to our findings for $A$. siamensis. Since the floral visitors of $A$. siamensis appear to be reliable and effective pollinators, insufficient fruit and seed set are likely not a primary cause of the limited distribution of this endemic species.

\subsection{Pollinator Observations}

When considering both foraging behavior and visitation rates, the likely pollinators of A. siamensis are stingless bees (Meliponini), blue-banded bees (Amegilla), and skipper butterflies (particularly $U$. folus). These results are consistent with previous research, as many species in the morning glory family are pollinated by bees and butterflies [12,13,17,30,33-43]. Stingless bees are often abundant in tropical pollinator assemblages [44-46], including in Thailand [47-49], and many tropical species of morning glory are known to be pollinated by stingless bees, such as Ipomoea carica, I. grandifolia, and I. nil [36]; I. aquatica [43]; I. wolcottiana [12]; I. hieronymi [50]; Merremia aegyptia [33]; M. macrocalyx [20]; and M. dissecta var edentada [37]. Reports of blue-banded bees visiting Convolvulaceae species are less common, but they have been observed visiting I. digitata [51], Jaquemontia sp. [52], and I. aquatica [43]. Moreover, Kato et al. [51] reported that, in Laos, Amegilla bees typically pollinate perennial, tubular flowers, which corresponds with the habit and morphology of our study species. Butterflies are also known to visit the flowers of Convolvulaceae species; however, they appear to be less important pollinators than bees due to their less reliable and infrequent visits $[17,40,53]$. Our results also indicate that skipper butterflies are less frequent visitors than bees, but they appear to be important pollinators in areas where bee visitation is low, as in the case we observed in the eastern population.

Interestingly, the composition and visitation rates of potential pollinators differed between our two study populations. In the western population, we observed only bees, whereas in the eastern population, we observed mostly butterflies, and occasionally bees, ants, and flies. Stingless bees were the only pollinator taxa observed visiting A. siamensis in both populations, although they visited flowers in the western population much more frequently than in the eastern population. The observed pollinator differences between the two populations may be due to the different habitats. In the western site, our study species was found on the forest floor of a bamboo forest bordering a waterfall, which might explain the abundance of bee visits at this site. Heard [45] reported that stingless bees often nest in stems or branches, including the stems of bamboo. Additionally, blue-banded bees build their nests in the soil, and Sandeep and Muthuraman [54] observed Amegilla zonata building nests in a bamboo garden. In contrast, the eastern population was located in 
grassland on high ground surrounded by hills (175-271 $\mathrm{m}$ above sea level). The more open habitat in the eastern site may explain the presence of butterflies and syrphid flies, which were not observed in the forested western population. Previous studies have reported that many butterfly species prefer open habitats over forested habitats [55-57], especially smaller butterflies [58] such as the Hesperiidae butterflies observed in this study. Similarly, Hall and Reboud [59] found that syrphid flies were more common in open habitats than wooded habitats. Our study suggests that $A$. siamensis likely depends on both bee and butterfly pollinators, depending on habitat type and the pollinator community present.

\subsection{Histochemistry}

We observed terpenes in both the floral nectary and staminal trichomes of $A$. siamensis. Terpenes have many functions in plants, including attracting pollinators and seed dispersers [24,60-62], as they are volatile compounds that can be found in flowers and fruits [63] and can even accumulate in nectar [64]. Terpenes emitted from floral tissues, in particular, are often specific to pollinator attraction [65]. Moreover, several studies have demonstrated that terpenes are perceived by insects $[62,66]$. For example, studying antenna response has demonstrated that many pollinators can detect terpenes, including hawkmoths [66,67], honeybees [68,69], and stingless bees [70,71]. Another study showed that terpenes are emitted from the petals, floral nectaries, stigmas, and anthers of Arabidopsis flowers, which function as both a defensive mechanism against pathogens and also as short-distance attractants for insect pollinators [72]. Since our study species is self-incompatible and dependent on pollinators for reproduction, the presence of terpenes in the floral nectary and glands of staminal trichomes suggests that $A$. siamensis produces these volatile compounds to attract insect pollinators.

We also observed flavonoids in the floral nectary and staminal trichomes. Flavonoids are secondary metabolites commonly found in flowering plants that contribute to floral color and have various biological functions, including pollinator attraction [73-78]. While many flavonoids are well-known for their role in pigmentation, such as anthocyanins [79], others are colorless to the human eye, such as flavones and flavonols [79,80]. These "colorless" flavonoids can actually absorb UV wavelengths and produce UV patterns, which can act as nectar guides for bees $[74,77,80]$. In this study, observation of $A$. siamensis flowers under a fluorescence microscope with a UV filter revealed that the staminal trichomes, although not the floral nectary, fluoresced under UV wavelengths. Since the main pollinators of $A$. siamensis are bees, which forage more efficiently with nectar guides [81,82], we hypothesize that flavonoids in the staminal trichomes may help guide bee pollinators to the floral nectary. Flavonoids have also been found in nectar [64], which may explain why we also detected them in the floral nectary, although their function is still unclear [64].

\subsection{Floral Nectary Anatomy and Micromorphology}

Microscopic observation of the floral nectary of $A$. siamensis revealed that the structure is similar to that of other species in the family Convolvulaceae $[50,83,84]$, and provides insight into its function. Similar to other morning glory species, $A$. siamensis has a discoidal nectary that surrounds the base of the ovary. Galetto and Bernardello [50] reported similar descriptions of floral nectaries for six Ipomoea (Convolvulaceae) species and suggested that it may be a conserved character within the family. The floral nectary is derived from nectariferous tissue, which comprises the epidermis, nectary parenchyma, and subnectary parenchyma [85-88], as we also observed in A. siamensis. The epidermis and nectary parenchyma contribute directly to nectar production and secretion, while the subnectary parenchyma appears to contribute indirectly to nectar production [88,89]. We also observed stomata distributed across the surface of the floral nectary, similar to previous reports for Ipomoea [50], Anemopaegma album [90], Viburnum opulus [91], Oenothera [92], and Geranium macrorrhizum and G. phaeum [93]. Galetto and Bernardello [50] described three types of stomata distribution along the nectary surface: uniform, only on the apex and base of the nectary, and only on the apex of the nectar; apical distribution was the most common 
type in their study, and also what we observed for $A$. siamensis. The stomata observed on floral nectaries are actually modified stomata that have lost the ability to close [88]; such stomata have been referred to as nectarostomata [88], and they serve to secrete nectar that is produced in the nectary parenchyma [94]. Both bees [95] and butterflies [96,97] forage on nectar, and our findings provide additional support for the importance of the floral nectary in attracting pollinators to $A$. siamensis flowers.

\subsection{Potential Causes of Rarity in A. siamensis}

Our results indicate that the rarity of $A$. siamensis is not caused by insufficient pollination. Instead, the small population sizes and limited distribution of $A$. siamensis may be due to low germination rates, poor dispersal, negative impacts caused by human activity, or some combination of these factors. It is likely that $A$. siamensis has low germination rates given that seedlings have never been observed at our study sites (Awapa Jirabanjongjit and Tomoki Sando, personal observation). We hypothesize that seed predators consume ripe fruits, as we typically only observe young fruits and empty bracts, indicating where a fruit had been removed (Tomoki Sando, personal observation). As Burmese striped squirrels (Tamiops mcclellandii) are often observed in the eastern study site (Tomoki Sando, personal observation), and rodents are known seed predators [98] (Crawley 2000), it is possible that this species is a seed predator of $A$. siamensis. Low germination rates (due to seed predation and/or poor germination ability) may thus explain why populations typically have fewer than 30 individuals, although empirical data are needed to confirm this conjecture. Additionally, poor dispersal ability may contribute to the limited distribution of $A$. siamensis. While the manner of seed dispersal has not been reported for A. siamensis, previous studies have reported other members in the genus Argyreia to be zoochorous (although the specific animal disperser taxa were not specified; [99-101]. Further observation is needed to determine whether $A$. siamensis has any seed dispersers. Finally, A. siamensis populations may be negatively impacted by habitat loss and other anthropogenic activity. For example, the western population occurs in an area that was mined for granite ore for nearly four decades before the government restored the area, and it is currently a popular eco-tourism site due to scenic waterfalls and views (Awapa Jirabanjongjit, personal communication). On the other hand, the eastern population appears to benefit from the moderate grazing activity of domestic water buffalo and cattle. These grazers maintain open habitat that A. siamensis appears to prefer, and it is often found growing near cattle trails (Tomoki Sando, personal observation). Unfortunately, the lack of data on A. siamensis prevents us from knowing whether anthropogenic activity has reduced the distribution of this species, or if it has always had a limited distribution. Regardless, the results of a meta-analysis indicate that self-incompatible and rare species, such as $A$. siamensis, are more likely to be negatively impacted by habitat fragmentation [102], emphasizing the need to protect this rare species.

\section{Material and Methods}

\subsection{Study Species and Study Sites}

Argyreia siamensis (Craib) Staples belongs to the morning glory family, also known as Convolvulaceae. Initially, this species was placed in the genus Ipomoea [11] until its fruits were found and proved that this species belongs to Argyreia [8,9]. According to the Flora of Thailand, A. siamensis is perennially deciduous with annual rhizomes [10]. Its leaves are ovate or ovate-orbicular and have pale leaf veins that are sometimes outlined with purple. Flowers have five stamens and a tubular-funnelform corolla; the corolla tube is white, and the corolla lobes are bright purple. When visually examining flowers, no nectar was observed (Awapa Jirabanjongjit, personal observation). Argyreia siamensis has brown berries with red sepals. This endemic species was originally thought to be found only in the northern and western regions of Thailand but has recently been found in the eastern region as well. It generally grows in the shaded understory of dipterocarp forests or in grassy areas on poor, rocky soil, over granite rock at altitudes of 475-1110 m. 
Flowering occurs from July to November [10], and flowers are open from around $05.00 \mathrm{~h}$ until approximately $06.00 \mathrm{~h}$ the following day (Awapa Jirabanjongjit, personal observation). Fruits are fully mature approximately $4-5$ weeks after fertilization (Awapa Jirabanjongjit, personal observation).

This study was conducted in two populations. The first was located in a deciduous forest in Ratchaburi Province (hereafter referred to as the "western population"), with around 10 individual plants. The second population was located in an area with both deciduous forest and grassland in Nakhon Ratchasima Province (hereafter, the "eastern population"), and had approximately 30 individual plants.

\subsection{Mating System}

To examine the mating system of $A$. siamensis, we conducted a pollination experiment with the following four treatments: open pollination (flowers were unmanipulated, and all animals could visit as normal), hand cross-pollination (each flower was emasculated before anthesis and then pollinated by hand after anthesis using pollen from a different individual), hand self-pollination (each flower was pollinated by hand using autogamous pollen), and the closed treatment (mature flower buds were covered with a mesh bag that prevented visits from animals throughout the entire anthesis period). In the western population, we used 32 flowers from 8 individuals, and in the eastern population, we used 32 flowers from 5 individuals. Fruits of successfully fertilized study flowers, as well as the withered flowers of those that were not successfully fertilized, were collected 2 weeks after the start of the experiment and dried at $60^{\circ} \mathrm{C}$ for 3 days. We then weighed all fruits, withered flowers, and seeds. In the eastern population, heavy rains shortly after the pollination experiment prevented the flowers from developing into mature fruits. We, therefore, measured ovary diameter as a proxy for whether or not flowers were successfully pollinated on the assumption that larger ovaries indicated they had started to develop into fruits before the heavy rains, and that smaller ovaries had likely not been successfully pollinated.

We used linear mixed modeling (LMM; function lmer in the R package "lme4") to examine the effect of pollination treatment on each of our response variables (fruit weight and seed weight for the western population, and ovary diameter for the eastern population). The response variables were $\ln$-transformed to improve the normality of the residuals. We used pollination treatment as the fixed factor and included plant ID as a random factor. We examined whether treatment was significant through nested likelihood ratio tests and, when the fixed factor was found to be significant, used Tukey's post hoc test to compare treatment levels (function emmeans in package "emmeans"). These analyses were conducted in $R$ version 4.0.2 [103].

\subsection{Pollinator Observations}

To study the potential pollinators of $A$. siamensis, all animal visitors were recorded by either a video camera (Sony CX405, Sony, New York, NY, USA) or an action camera (Xiaomi YI Z15, Xiaomi, Beijing, China) during both day (06.00-18.00 h) and night (18.00-06.00 h) for 3 days per population. We observed 13 flowers in the western population and 11 flowers in the eastern population. All footage was reviewed, and we recorded each animal visitor, its behavior, and the time of visitation. Animals were identified to the lowest taxonomic level possible using field guides [104,105]. Animals were considered visitors if they did not contact floral reproductive structures, and pollinators if they did contact the stigmas and anthers. Only pollinators were included in subsequent analyses.

We used LMM (function lmer in the R package "lme4") to determine whether there were significant differences between the visitation rates of each pollinator species. Visitation rates were $\ln$-transformed to improve the normality of the residuals. We used pollinator taxa as the fixed factor and included plant ID as a random factor. The significance of the fixed factor was examined with nested likelihood ratio tests. When the fixed factor was significant, Tukey's post hoc test was performed to determine which pairs of pollinator 
taxa were significantly different (function emmeans in package "emmeans"). These analyses were conducted in $\mathrm{R}$ version 4.0.2 [103].

\subsection{Histochemistry}

We used histochemical techniques to assess the presence of phytochemical compounds of interest in the floral nectary and staminal trichomes (i.e., trichomes found on the base of the stamens). In total, 15 flowers from each population were collected. The nectary discs of fresh flowers were free-hand sectioned (both transverse and longitudinally), and stamens were removed at the base (where the filaments attached to the petals) to examine the staminal trichomes. The nectary sections and whole stamens were stained with NADI reagent (5 flowers per population) to test for terpenes $[106,107]$ and Naturstoff reagent A (5 flowers per population) to test for flavonoids [107,108]. We also used a fluorescence microscope (Olympus BX53) with a UV filter to observe any natural fluorescence by the floral nectary and staminal trichomes (5 flowers per population).

\subsection{Floral Nectary Anatomy and Micromorphology}

To examine the characters of the floral nectary, six flowers from different individuals were collected from each population and fixed in $70 \%$ alcohol. Three of these spirit specimens were examined with a scanning electron microscope (Hitachi SU8010) $[38,109]$ to study the surface of the floral nectary. The other three spirit specimens were examined via anatomical techniques using the paraffin method [89,110-112]. Briefly, the paraffin method requires all water to be removed from the spirit specimens by first using a vacuum and then dehydrating the tissue with tert-Butyl alcohol (TBA) series [89,110-112]. Then, the specimens are infiltrated with paraplast and embedded in the medium [89,110-112]. Longitudinal and transverse sections were prepared with a sliding microtome (Leica SM2000 R), stained with safranin-O and fast green, and we then examined the nectary epidermis, nectary parenchyma, and subnectary parenchyma by light microscope (Olympus BX43 with a DP21 camera set).

\section{Conclusions}

Argyreia siamensis is a rare plant species endemic to Thailand, but little is known about the species, and why it is rare. Our findings reveal that $A$. siamensis is self-incompatible and therefore dependent on pollinators. However, we did not find evidence for pollen limitation, which indicates that its pollinators are reliable and effective. The main pollinators of A. siamensis appear to be bees (Meliponini and Amegilla) and butterflies (Hesperiidae). Moreover, our results suggest that $A$. siamensis uses terpenes (likely as an olfactory cue) and flavonoids (possibly as a visual cue) in the floral nectary and staminal trichomes to attract and guide pollinators. The floral nectary comprises the epidermis (with nectarostomata), nectary parenchyma (with secretory ducts), and subnectary parenchyma, all of which indicate that $A$. siamensis provides pollinators with a nectar reward, despite nectar not collecting in obvious quantities within the flower. Although A. siamensis is rare and has a limited geographical range, the findings from this study indicate that insufficient pollination is likely not a primary cause. Further research is necessary to determine the conservation status of $A$. siamensis and factors contributing to its rarity.

Author Contributions: Conceptualization, P.T., A.B.S. and A.J.; methodology, A.B.S., P.T., A.J. and T.S.; data collection, A.J. and T.S.; data analysis, A.J., A.B.S. and P.T.; writing-original draft preparation, A.J. and A.B.S.; writing-review and editing, A.J., A.B.S., P.T. and T.S.; supervision, A.B.S. and P.T.; funding acquisition, P.T. and A.B.S. All authors have read and agreed to the published version of the manuscript.

Funding: This research was funded by Mahidol University (Frontier Research Grant awarded to P.T. and A.B.S.). 
Institutional Review Board Statement: The study was conducted according to the guidelines of IACUC, and approved by the Institutional Animal Care and Use Committee of the Faculty of Science at Mahidol University (Protocol Number MUSC60-037-387, approved 15 December 2017).

Data Availability Statement: The data presented in this study are openly available in Mendeley Data at DOI: 10.17632/c5m8gz95p5.1.Ethics Approval: Permission to work with animals was granted by MUSC-IACUC (Faculty of Science, Mahidol University-Institutional Animal Care and Use Committee) (Protocol Number MUSC60-037-387, approved 15 December 2017).

Acknowledgments: We are thankful to Kanjana Pramali, Natthaphong Chitchak, Wipawee Nilapaka, Kanapol Ketjarun, Yanisa Olaranont, Pantamith Ratanakrajang, and Poompat Srisombat for their assistance with fieldwork, and for helpful advice regarding laboratory work. We also thank three anonymous reviewers for their constructive comments.

Conflicts of Interest: The authors declare no conflict of interest.

Ethics Approval: Permission to work with animals was granted by MUSC-IACUC (Faculty of Science, Mahidol University-Institutional Animal Care and Use Committee) (Protocol Number MUSC60-037-387, approved 15 December 2017).

\section{References}

1. Mittermeier, R.A.; Myers, N.; Thomsen, J.B.; Da Fonseca, G.A.; Olivieri, S. Biodiversity hotspots and major tropical wilderness areas: Approaches to setting conservation priorities. Conserv. Biol. 1998, 12, 516-520. [CrossRef]

2. Myers, N.; Mittermeier, R.A.; Mittermeier, C.G.; Da Fonseca, G.A.; Kent, J. Biodiversity hotspots for conservation priorities. Nature 2000, 403, 853-858. [CrossRef]

3. Joppa, L.N.; Roberts, D.L.; Myers, N.; Pimm, S.L. Biodiversity hotspots house most undiscovered plant species. Proc. Natl. Acad. Sci. USA 2011, 108, 13171-13176. [CrossRef]

4. Morais, A.R.; Siqueira, M.N.; Lemes, P.; Maciel, N.M.; De Marco, P., Jr.; Brito, D. Unraveling the conservation status of Data Deficient species. Biol. Conserv. 2013, 166, 98-102. [CrossRef]

5. Bland, L.M.; Collen, B.E.N.; Orme, C.D.L.; Bielby, J.O.N. Predicting the conservation status of data-deficient species. Conserv. Biol. 2014, 29, 250-259. [CrossRef] [PubMed]

6. Parsons, E.C.M. Why IUCN should replace "data deficient" conservation status with a precautionary "assume threatened" status-a cetacean case study. Front. Mar. Sci. 2016, 3, 193. [CrossRef]

7. Roberts, D.L.; Taylor, L.; Joppa, L.N. Threatened or data deficient: Assessing the conservation status of poorly known species. Divers. Distrib. 2016, 22, 558-565. [CrossRef]

8. Staples, G.W. New combinations in Thai Convolvulaceae. Thai Forest Bull. (Bot.) 2004, 32, 149-150.

9. Staples, G.W.; Traiperm, P. A nomenclatural review of Argyreia (Convolvulaceae). Taxon 2017, 66, 445-477. [CrossRef]

10. Staples, G.W.; Traiperm, P. Argyreia Lour. In Flora of Thailand; Santisuk, T., Larsen, K., Eds.; The Forest Herbarium: Bangkok, Thailand, 2010; Volume 10, pp. 337-371.

11. Craib, W.G. Contributions to the Flora of Siam. II. List of Siamese plants, with descriptions of new species. Bull. Misc. Inf. 1911, 1911, 385-448. [CrossRef]

12. Bullock, S.H.; Ayala, R.; Baker, I.; Baker, H.G. Reproductive biology of the tree Ipomoea wolcottiana (Convolvulaceae). Madroño 1987, 34, 304-314.

13. Pick, R.A.; Schlindwein, C. Pollen partitioning of three species of Convolvulaceae among oligolectic bees in the Caatinga of Brazil. Plant Syst. Evol. 2011, 293, 147-159. [CrossRef]

14. Kowyama, Y.; Tsuchiya, T.; Kakeda, K. Sporophytic self-incompatibility in Ipomoea trifida, a close relative of sweet potato. Ann. Bot. 2000, 85, 191-196. [CrossRef]

15. Devall, M.S.; Thien, L.B. Self-incompatibility in Ipomoea pes-caprae (Convolvulaceae). Am. Midl. Nat. 1992, 128, 22-29. [CrossRef]

16. Hull-Sanders, H.M.; Eubanks, M.D.; Carr, D.E. Inbreeding depression and selfing rate of Ipomoea hederacea var. integriuscula (Convolvulaceae). Am. J. Bot. 2005, 92, 1871-1877. [CrossRef] [PubMed]

17. Da Paz, J.R.L.; Gimenes, M.; Pigozzo, C.M. Three diurnal patterns of anthesis in Ipomoea carnea subsp. fistulosa (Convolvulaceae): Implications for temporal, behavioral and morphological characteristics of pollinators? Flora-Morphol. Distrib. Funct. Ecol. Plants 2013, 208, 138-146. [CrossRef]

18. Mcmullen, C.K. Pollination biology of a night-flowering Galápagos endemic, Ipomoea habeliana (Convolvulaceae). Bot. J. Linn. Soc. 2009, 160, 11-20. [CrossRef]

19. Ushimaru, A.; Kikuzawa, K. Variation of breeding system, floral rewards, and reproductive success in clonal Calystegia species (Convolvulaceae). Am. J. Bot. 1999, 86, 436-446. [CrossRef] [PubMed]

20. Raimúndez-Urrutia, E.; Avendaño, L.; Velázquez, D. Reproductive biology of the morning glory Merremia macrocalyx (Ruiz \& Pavon) O'Donnell (Convolvulaceae). J. Torrey Bot. Soc. 2008, 135, 299-308.

21. Whitehouse, H.L. Multiple-allelomorph incompatibility of pollen and style in the evolution of the angiosperms. Ann. Bot. 1950, 14, 199-216. [CrossRef] 
22. Narayanapur, V.B.; Suma, B.; Minimol, J.S. Self-incompatibility: A pollination control mechanism in plants. Int. J. Plant Sci. 2018, 13, 201-212. [CrossRef]

23. Richards, A.J. Plant Breeding Systems; Chapman \& Hall: London, UK, 1997.

24. Buchmann, S.L.; Nabhan, G.P. The Forgotten Pollinators; Island: Washington, DC, USA, 1996.

25. Liu, H.; Koptur, S. Breeding system and pollination of a narrowly endemic herb of the Lower Florida Keys: Impacts of the urban-wildland interface. Am. J. Bot. 2003, 90, 1180-1187. [CrossRef]

26. Knight, T.M.; Steets, J.A.; Vamosi, J.C.; Mazer, S.J.; Burd, M.; Campbell, D.R.; Dudash, M.R.; Johnston, M.O.; Mitchell, R.J.; Ashman, T.L. Pollen limitation of plant reproduction: Pattern and process. Annu. Rev. Ecol. Evol. Syst. 2005, 36, 467-497. [CrossRef]

27. Larson, B.M.; Barrett, S.C. A comparative analysis of pollen limitation in flowering plants. Biol. J. Linn. Soc. 2000, 69, 503-520. [CrossRef]

28. Willmott, A.P.; Burquez, A. The pollination of Merremia palmeri (Convolvulaceae): Can hawk moths be trusted? Am. J. Bot. 1996, 83, 1050-1056. [CrossRef]

29. Wolf, A.T.; Harrison, S.P. Effects of habitat size and patch isolation on reproductive success of the serpentine morning glory. Conserv. Biol. 2001, 15, 111-121. [CrossRef]

30. Delgado-Dávila, R.; Martén-Rodríguez, S.; Huerta-Ramos, G. Variation in floral morphology and plant reproductive success in four Ipomoea species (Convolvulaceae) with contrasting breeding systems. Plant Biol. 2016, 18, 903-912. [CrossRef]

31. Garwood, N.C.; Horvitz, C.C. Factors limiting fruit and seed production of a temperate shrub, Staphylea trifolia L. (Staphyleaceae). Am. J. Bot. 1985, 72, 453-466. [CrossRef]

32. Byers, D.L. Pollen quantity and quality as explanations for low seed set in small populations exemplified by Eupatorium (Asteraceae). Am. J. Bot. 1995, 82, 1000-1006. [CrossRef]

33. Kiill, L.H.P.; Ranga, N.T. Pollination ecology of Ipomoea asarifolia (Ders.) Roem. \& Schult.(Convolvulaceae) in the semi-arid area of Pernambuco. Acta Bot. Bras. 2003, 17, 355-362.

34. Keeler, K.H. Ipomoea carnea Jacq. (Convolvulaceae) in Costa Rica. Fac. Publ. Biol. Sci. 1975, 5, 1-6.

35. Parra-Tabla, V.; Bullock, S.H. Factors limiting fecundity of the tropical tree Ipomoea wolcottiana (Convolvulaceae) in a Mexican tropical dry forest. J. Trop. Ecol. 1998, 14, 615-627. [CrossRef]

36. Maimoni-Rodella, R.C.S.; Yanagizawa, Y.A.N.P. Floral biology and breeding system of three Ipomoea weeds. Planta Daninha 2007, 25, 35-42. [CrossRef]

37. Paz, J.R.L.; Pigozzo, C.M. Floral biology and pollination of Merremia dissecta var. edentada (Meisn.) O'Donnell (Convolvulaceae) in an urban fragment of Atlantic Forest, Bahia. Lundiana 2013, 11, 9-16.

38. Ketjarun, K.; Traiperm, P.; Suddee, S.; Watthana, S.; Gale, S.W. Labellar anatomy of the Nervilia plicata complex (Orchidaceae: Epidendroideae) in tropical Asia. Kew Bull. 2019, 74, 1-13. [CrossRef]

39. Santos, S.K.; Gimenes, M. The efficiency of bees in pollinating ephemeral flowers of Jacquemontia bracteosa (Convolvulaceae). Iheringia. Série Zool. 2016, 106, 467-497. [CrossRef]

40. Araujo, L.S.; Medina, A.M.; Gimenes, M. Pollination efficiency on Ipomoea bahiensis (Convolvulaceae): Morphological and behavioural aspects of floral visitors. Iheringia. Série Zool. 2018, 108, 1-5. [CrossRef]

41. Chitchak, N.; Traiperm, P.; Staples, G.; Rattanakrajang, P.; Sumanon, P. Species delimitation of some Argyreia (Convolvulaceae) using phenetic analyses: Insights from leaf anatomical data reveal a new species. Botany 2018, 96, 217-233. [CrossRef]

42. Shay, K.R.; Drake, D.R. Pollination Biology of the Hawaiian Coastal Vine Jacquemontia sandwicensis (Convolvulaceae). Pac. Sci. 2018, 72, 485-499. [CrossRef]

43. Hassa, P.; Traiperm, P.; Stewart, A.B. Pollinator visitation and female reproductive success in two floral color morphs of Ipomoea aquatica (Convolvulaceae). Plant Syst. Evol. 2020, 306, 1-11. [CrossRef]

44. Inoue, T.; Salmah, S.; Abas, I.; Yusuf, E. Foraging behavior of individual workers and foraging dynamics of colonies of three Sumatran stingless bees. Res. Popul. Ecol. 1985, 27, 373-392. [CrossRef]

45. Heard, T.A. The role of stingless bees in crop pollination. Annu. Rev. Entomol. 1999, 44, 183-206. [CrossRef]

46. Slaa, E.J.; Chaves, L.A.S.; Malagodi-Braga, K.S.; Hofstede, F.E. Stingless bees in applied pollination: Practice and perspectives. Apidologie 2006, 37, 293-315. [CrossRef]

47. Schwarz, H.F. Results of the Oxford University Sarawak (Borneo) expedition: Bornean stingless bees of the genus Trigona. Bull. Am. Mus. Nat. Hist. 1937, 73, 281-328.

48. Stewart, A.B.; Sritongchuay, T.; Teartisup, P.; Kaewsomboon, S.; Bumrungsri, S. Habitat and landscape factors influence pollinators in a tropical megacity, Bangkok, Thailand. Peer] 2018, 6, e5335. [CrossRef] [PubMed]

49. Stewart, A.B.; Waitayachart, P. Year-round temporal stability of a tropical, urban plant-pollinator network. PLoS ONE 2020, 15, e0230490. [CrossRef] [PubMed]

50. Galetto, L.; Bernardello, G. Floral nectaries, nectar production dynamics and chemical composition in six Ipomoea species (Convolvulaceae) in relation to pollinators. Ann. Bot. 2004, 94, 269-280. [CrossRef]

51. Kato, M.; Kosaka, Y.; Kawakita, A.; Okuyama, Y.; Kobayashi, C.; Phimminith, T.; Thongphan, D. Plant-pollinator interactions in tropical monsoon forests in Southeast Asia. Am. J. Bot. 2008, 95, 1375-1394. [CrossRef] [PubMed]

52. Pratheepa, M.; Amala, U.; Shivalingaswamy, T.M. Biodiversity of pollinators in four bee-friendly plant species. J. Biol. Control 2019, 33, 360-364. [CrossRef] 
53. De Souza Pacheco Filho, A.J.; Westerkamp, C.; Freitas, B.M. Ipomoea bahiensis pollinators: Bees or butterflies? Flora-Morphol. Distrib. Funct. Ecol. Plants 2011, 206, 662-667. [CrossRef]

54. Sandeep, K.J.; Muthuraman, M. Bio-ecology of blue banded bees, Amegilla zonata L. (Apidae: Hymenoptera). J. Entomol. Zool. Stud. 2019, 7, 428-434.

55. Erhardt, A. Diurnal Lepidoptera: Sensitive indicators of cultivated and abandoned grassland. J. Appl. Ecol. 1985, $223,849-861$. [CrossRef]

56. Schmitt, T. Influence of forest and grassland management on the diversity and conservation of butterflies and burnet moths (Lepidoptera, Papilionoidea, Hesperiidae, Zygaenidae). Anim. Biodivers. Conserv. 2003, 26, 51-67.

57. Nacua, A.E.; Mohagan, A.B.; Alejandro, G.J.D. Species Composition and Status of Butterflies in the Sunny and Shady Habitats of Cadaclan, San Fernando, La Union Botanical Garden of North Luzon, Philippines. IAMURE Int. J. Ecol. Conserv. 2015, 13, 63. [CrossRef]

58. Xing, S.; Bonebrake, T.C.; Tang, C.C.; Pickett, E.J.; Cheng, W.; Greenspan, S.E.; Williams, S.E.; Scheffers, B.R. Cool habitats support darker and bigger butterflies in Australian tropical forests. Ecol. Evol. 2016, 6, 8062-8074. [CrossRef] [PubMed]

59. Hall, M.A.; Reboud, E.L. High sampling effectiveness for non-bee flower visitors using vane traps in both open and wooded habitats. Austral Entomol. 2019, 58, 836-847. [CrossRef]

60. Dudareva, N.; Pichersky, E. Biochemical and molecular genetic aspects of floral scents. Plant Physiol. 2000, 122, 627-634. [CrossRef] [PubMed]

61. Dudareva, N.; Negre, F.; Nagegowda, D.A.; Orlova, I. Plant volatiles: Recent advances and future perspectives. Crit. Rev. Plant Sci. 2006, 25, 417-440. [CrossRef]

62. Gershenzon, J.; Dudareva, N. The function of terpene natural products in the natural world. Nat. Chem. Biol. 2007, 3, 408-414. [CrossRef] [PubMed]

63. Knudsen, J.T.; Eriksson, R.; Gershenzon, J.; Stahl, B. Diversity and distribution of floral scent. Bot. Rev. 2006, 72, 1-120. [CrossRef]

64. Nicolson, S.W.; Thornburg, R.W. Nectar chemistry. In Nectaries and Nectar; Springer: Dordrecht, The Netherlands, 2007; pp. 215-264.

65. Tholl, D. Terpene synthases and the regulation, diversity and biological roles of terpene metabolism. Curr. Opin. Plant Biol. 2006, 9, 297-304. [CrossRef] [PubMed]

66. Raguso, R.A.; Light, D.M. Electroantennogram responses of male Sphinx perelegans hawkmoths to floral and "green-leaf volatiles". Entomol. Exp. Et Appl. 1998, 86, 287-293. [CrossRef]

67. Shields, V.D.C.; Hildebrand, J.G. Responses of a population of antennal olfactory receptor cells in the female moth Manduca sexta to plant-associated volatile organic compounds. J. Comp. Physiol. A 2001, 186, 1135-1151. [CrossRef]

68. Wright, G.A.; Lutmerding, A.; Dudareva, N.; Smith, B.H. Intensity and the ratios of compounds in the scent of snapdragon flowers affect scent discrimination by honeybees (Apis mellifera). J. Comp. Physiol. A 2005, 191, 105-114. [CrossRef]

69. Jung, J.W.; Park, K.W.; Oh, H.W.; Kwon, H.W. Structural and functional differences in the antennal olfactory system of worker honey bees of Apis mellifera and Apis cerana. J. Asia-Pac. Entomol. 2014, 17, 639-646. [CrossRef]

70. Patricio, E.F.L.R.A.; Cruz-López, L.; Morgan, E.D. Electroantennography in the study of two stingless bee species (Hymenoptera: Meliponini). Braz. J. Biol. 2004, 64, 827-831. [CrossRef]

71. Leonhardt, S.D.; Zeilhofer, S.; Blüthgen, N.; Schmitt, T. Stingless bees use terpenes as olfactory cues to find resin sources. Chem. Senses 2010, 35, 603-611. [CrossRef] [PubMed]

72. Chen, F.; Tholl, D.; D'Auria, J.C.; Farooq, A.; Pichersky, E.; Gershenzon, J. Biosynthesis and emission of terpenoid volatiles from Arabidopsis flowers. Plant Cell 2003, 15, 481-494. [CrossRef] [PubMed]

73. Bohm, B.A. Introduction to Flavonoids; Hardwood Academic Publishers: Amsterdam, The Netherlands, 1998 ; pp. 365-394.

74. Iwashina, T. Flavonoid function and activity to plants and other organisms. Biol. Sci. Space 2003, 17, 24-44. [CrossRef] [PubMed]

75. Griesbach, R.J. Biochemistry and genetics of flower color. Plant Breed. Rev. 2005, 25, 89-114.

76. Gould, K.S.; Lister, C. Flavonoid functions in plants. In Flavonoids: Chemistry, Biochemistry and Applications; CRC Press: Boca Raton, FL, USA, 2006; pp. 397-441.

77. Samanta, A.; Das, G.; Das, S.K. Roles of flavonoids in plants. Carbon 2011, 100, 12-35.

78. Agati, G.; Azzarello, E.; Pollastri, S.; Tattini, M. Flavonoids as antioxidants in plants: Location and functional significance. Plant Sci. 2012, 196, 67-76. [CrossRef] [PubMed]

79. Iwashina, T. The structure and distribution of the flavonoids in plants. J. Plant Res. 2000, 113, 287. [CrossRef]

80. Thompson, W.R.; Meinwald, J.; Aneshansley, D.; Eisner, T. Flavonols: Pigments responsible for ultraviolet absorption in nectar guide of flower. Science 1972, 177, 528-530. [CrossRef]

81. Leonard, A.S.; Papaj, D.R. 'X'marks the spot: The possible benefits of nectar guides to bees and plants. Funct. Ecol. 2011, 25, 1293-1301. [CrossRef]

82. Schlindwein, C.; Westerkamp, C.; Carvalho, A.T.; Milet-Pinheiro, P. Visual signalling of nectar-offering flowers and specific morphological traits favour robust bee pollinators in the mass-flowering tree Handroanthus impetiginosus (Bignoniaceae). Bot. J. Linn. Soc. 2014, 176, 396-407. [CrossRef]

83. Govil, C.M. Morphological studies in the family Convolvulaceae. Proc. Indian Acad. Sci.-Sect. B 1972, 75, 271-282. [CrossRef]

84. Stucky, J.M.; Beckmann, R.L. Pollination biology, self-incompatibility, and sterility in Ipomoea pandurata (L.) GFW Meyer (Convolvulaceae). Am. J. Bot. 1982, 69, 1022-1031. [CrossRef] 
85. Fahn, A. Secretory Tissues in Plants; Academic Press: London, UK, 1979.

86. Fahn, A. Secretory tissues in vascular plants. New Phytol. 1988, 108, 229-257. [CrossRef]

87. Fahn, A. Structure and function of secretory cells. Adv. Bot. Res. 2000, 31, 37-75.

88. Nepi, M. Nectary structure and ultrastructure. In Nectaries and Nectar; Springer: Dordrecht, The Netherlands, 2007; pp. 129-166.

89. Rattanakrajang, P.; Traiperm, P.; Staples, G.W. Re-evaluation of generic characters for Blinkworthia (Convolvulaceae) based on morphology and reproductive organ development. Plant Syst. Evol. 2018, 304, 415-429. [CrossRef]

90. Guimarães, E.; Nogueira, A.; Machado, S.R. Floral nectar production and nectary structure of a bee-pollinated shrub from Neotropical savanna. Plant Biol. 2016, 18, 26-36. [CrossRef] [PubMed]

91. Konarska, A. Comparative micromorphology and anatomy of flowers and floral secretory structures in two Viburnum species. Protoplasma 2017, 254, 523-537. [CrossRef] [PubMed]

92. Antoń, S.; Komoń-Janczara, E.; Denisow, B. Floral nectary, nectar production dynamics and chemical composition in five nocturnal Oenothera species (Onagraceae) in relation to floral visitors. Planta 2017, 246, 1051-1067. [CrossRef]

93. Konarska, A.; Masierowska, M. Structure of floral nectaries and female-biased nectar production in protandrous species Geranium macrorrhizum and Geranium phaeum. Protoplasma 2019, 257, 501-523. [CrossRef] [PubMed]

94. Pacini, E.; Nepi, M. Nectar production and presentation. In Nectaries and Nectar; Springer: Dordrecht, The Netherlands, 2007; pp. 167-214.

95. Nicolson, S.W. Bee food: The chemistry and nutritional value of nectar, pollen and mixtures of the two. Afr. Zool. 2011, 46, 197-204. [CrossRef]

96. Baker, H.G.; Baker, I. Amino-acids in nectar and their evolutionary significance. Nature 1973, 241, 543-545. [CrossRef]

97. Reddi, C.S.; Bai, G.M. Butterflies and pollination biology. Proc. Anim. Sci. 1984, 93, 391-396. [CrossRef]

98. Crawley, M.J. Seed predators and plant population dynamics. In Seeds: The Ecology of Regeneration in Plant Communities, 2nd ed.; CABI Publishing: Wallingford, UK, 2000; pp. 167-182.

99. Razi, B.A. A contribution towards the study of the dispersal mechanisms in flowering plants of Mysore (south India). Ecology 1950, 31, 282-286. [CrossRef]

100. Hebbar, R.; Sashidhar, V.R.; Shaanker, R.U.; Kumar, M.U.; Sudharshana, L. Dispersal mode of species influences the trypsin inhibitor levels in fruits. Naturewissenschaften 1993, 80, 519-521. [CrossRef]

101. Muthumperumal, C.; Parthasarathy, N. Diversity, distribution and resource values of woody climbers in tropical forests of southern Eastern Ghats, India. J. For. Res. 2013, 24, 365-374. [CrossRef]

102. Leimu, R.; Mutikainen, P.I.A.; Koricheva, J.; Fischer, M. How general are positive relationships between plant population size, fitness and genetic variation? J. Ecol. 2006, 94, 942-952. [CrossRef]

103. R Core Team. R: A language and Environment for Statistical Computing; R Foundation for Statistical Computing: Vienna, Austria, 2020, Available online: https:/ / www.R-project.org/ (accessed on 3 November 2021).

104. Suwanphak, K. Thailand Butterfly Guide, 1st ed.; Sarakadee: Nonthaburi, Thailand, 2013.

105. Suwanphak, K. Thailand Insect Guide, 1st ed.; Sarakadee: Nonthaburi, Thailand, 2016.

106. David, R.; Carde, J.P. Histochimie-coloration differentielle des inclusions lipidiques et terpeniques des pseudophylles du pin maritime au moyen du reactif NADI. Comptes Rendus Hebd. Des Seances De L Acad. Des Sci. 1964, 258, 1338.

107. Olaranont, Y.; Stauffer, F.; Traiperm, P.; Staples, G.W. Investigation of the black dots on leaves of Stictocardia species (Convolvulaceae) using anatomical and histochemical analyses. Flora Morphol. Distrib. Funct. Ecol. Plants 2018, 249, 133-142. [CrossRef]

108. Tattini, M.; Gravano, E.; Pinelli, P.; Mulinacci, N.; Romani, A. Flavonoids accumulate in leaves and glandular trichomes of Phillyrea latifolia exposed to excess solar radiation. New Phytol. 2000, 148, 69-77. [CrossRef] [PubMed]

109. Staples, G.W.; Traiperm, P.; Chow, J. Another new Thai Argyreia species (Convolvulaceae). Phytotaxa 2015, 204, 223-229. [CrossRef]

110. Johansen, D.A. Plant Microtechnique; McGraw-Hill Publishing Co., Ltd.: London, UK, 1940.

111. Arthan, W.; Traiperm, P.; Gale, S.W.; Norsaengsri, M.; Kethirun, L. Re-evaluation of the taxonomic status of Hackelochloa (Poaceae) based on anatomical and phenetic analyses. Bot. J. Linn. Soc. 2016, 181, 224-245. [CrossRef]

112. Traiperm, P.; Chow, J.; Nopun, P.; Staples, G.W.; Swangpol, S.C. Identification among morphologically similar Argyreia (Convolvulaceae) based on leaf anatomy and phenetic analyses. Bot. Stud. 2017, 58, 25. [CrossRef] [PubMed] 